\title{
ANALISIS FRAUD MENGGUNAKAN FINANCIAL SHENANIGANS PADA PT PERUSAHAAN GAS NEGARA (PERSERO) TBK
}

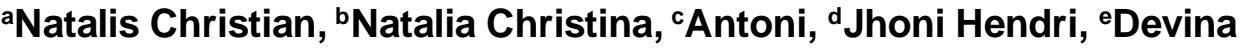 \\ abcdeUniversitas Internasional Batam \\ natalis.christian@uib.ac.id
}

\begin{tabular}{l|l|l} 
Received: August & Accepted: October & Published: December
\end{tabular}

\begin{abstract}
ABSTRAK
Tujuan utama dari penelitian ini adalah untuk mengkaji apakah terdapat kecurangan dalam penyajian laporan keuangan perusahaan dengan menggunakan tujuh financial shenanigans. Ruang lingkup dari penelitian ini adalah PT Perusahaan Gas Negara (Persero) Tbk. yang merupakan perseroan milik negara yang terdaftar pada indeks LQ45. Penelitian ini menggunakan metode kualitatif dan menggunakan teknik analisis data dalam menganalisis laporan keuangan perusahaan periode 2016 sampai tahun 2020. Hasil penelitian ini adalah dari kelima periode laporan keuangan yang dianalisis menggunakan tujuh financial shenanigans, tidak ditemukan adanya kecurangan yang menggunakan financial shenanigans dalam penyajian laporan keuangan sehingga dapat disimpulkan bahwa laporan keuangan PT Perusahaan Gas Negara (Persero) Tbk. telah disajikan dengan wajar dan sesuai dengan standar pelaporan akuntansi di Indonesia.
\end{abstract}

Kata Kunci: Financial shenanigans, Kecurangan, Laporan Keuangan, Perusahaan, Teknik.

\section{ABSTRACT}

The main purpose of this research is to examine whether there is fraud in the presentation of the company's financial statements using seven financial shenanigans. The scope of this research is PT Perusahaan Gas Negara (Persero) Tbk. which is a state-owned company listed on the LQ45 index. This research uses qualitative methods and uses data analysis techniques in analyzing the company's financial statements for the period 2016 to 2020. The results of this research are from the five financial reporting periods analyzed using financial shenanigans, no fraud was found using financial shenanigans in the presentation of financial statements so that it can concluded that the financial statements of PT Perusahaan Gas Negara (Persero) Tbk. has been presented fairly and in accordance with accounting reporting standards in Indonesia.

Keywords: Company, Financial shenanigans, Financial statements, Fraud, Techniques.

\section{PENDAHULUAN}

Laporan keuangan merupakan salah satu bentuk komunikasi antara perusahaan dengan pemangku kepentingan (Yesiariani \& Rahayu, 2017). Hal ini menyebabkan laporan keuangan harus disajikan secara benar agar dapat digunakan oleh pihak yang berkepentingan dalam mengambil keputusan. Akan tetapi, ditemukan beberapa faktor yang memicu seseorang untuk melakukan fraud yaitu fraud triangle. Fraud yang dilakukan menyebabkan laporan keuangan perusahaan tidak mencerminkankeadaan perusahaan yang sesungguhnya sehingga menyebabkan laporan keuangan tersebut menjadi tidak wajar. 
Kasus fraud merupakan sebuah fenomena yang besar dan terus meningkat setiap tahunnya. PricewaterhouseCoopers (PwC) dalam Global Economic Crime Survey tahun 2020 melaporkan bahwa 51\% dari fraud yang teridentifikasi melebihi US $\$ 100,000$ dan kerugian yang ditimbulkan selama 24 bulan terakhir melebihi US\$42 billion (Kuruppu, 2020). Berdasarkan survei yang dilakukan oleh Association of Certified Fraud Examiners (ACFE), kasus fraud di kawasan Asia Pasifik tergolong cukup besar. Pada tahun 2018, penipuan laporan keuangan menyebabkan kerugian sebesar US\$700,000 dan meningkat pada tahun 2020 dengan kerugian sebesar US $\$ 3,000,000$ (Sakti, Tarjo, Prasetyono, \& Riskiyadi, 2020).

Terdapat banyak jenis fraud yang dilakukan oleh perusahaan. Salah satu fraud yang dilakukan adalah fraudulent statement yang merupakan upaya perusahaan untuk melaporkan laporan keuangan secara tidak benar. Jenis fraud tersebut memiliki dampak yang paling signifikan diantara jenis fraud lainnya (Yesiariani \& Rahayu, 2017). Fraudulent statement memiliki tujuan yaitu pada umumnya adalah untuk melakukan manajemen laba dan teknik umum yang digunakan oleh perusahaan dalam melakukan fraud tersebut adalah melalui financial shenanigans. Financial shenanigans adalah segala bentuk tindakan yang bertujuan untuk memberikan gambaran mengenai laporan keuangan yang salah. Financial shenanigans berkaitan erat dengan kecurangan laporan keuangan. Kecurangan laporan keuangan adalah kesalahan penyajian yang disengajakan dengan tujuan untuk menipu pengguna laporan keuangan, terutama investor. Financial shenanigans dapat diartikan juga sebagai perilaku atau tindakan-tindakan curang yang digunakan oleh suatu perusahaan dalam melakukan kecurangan laporan keuangan (Jamieson, Awolowo, Garrow, Winfield, \& Bhaiyat, 2019).

Metode yang sering digunakan oleh seorang akuntan dalam tindakan kecurangannya yaitu dengan membuat jurnal entri yang palsu untuk menyembunyikan penyalahgunaan aset. Ketika fraudster berhasil dalam menggabungkan jurnal entri palsu di antara jurnal entri yang sebenarnya, auditor akan kesulitan dalam menemukan kecurangan. Hal ini mendorong kebutuhan dari auditor dan investigator mengenai suatu pedoman yang dapat digunakan untuk mendeteksi tindakan kecurangan yang dilakukan oleh manajemen perusahaan (Kuruppu, 2020).

Kasus fraud kerap ditemukan di Indonesia dan terkadang membawa kerugian yang signifikan bagi negara. Salah satu perusahaan yang terlibat dalam kasus fraud yaitu PT.Garuda Indonesia Tbk. Tepatnya pada bulan April 2019, PT Garuda Indonesia (Persero) Tbk. dituduh memanipulasi laporan keuangan tahun buku 2018 melalui pengungkapan pada laporan keuangan yaitu pendapatan sebesar USD809 juta, angka tersebut melonjak jauh apabila dibanding laporan keuangan tahun buku 2017 yang mencatat kerugian USD216,58 juta. Akibat adanya pelanggaran PT.Garuda Indonesia Tbk terhadap Standar Laporan Keuangan maka Kementerian Keuangan bertindak bersama-sama dengan Otoritas Jasa Keuangan (OJK) dan Bursa Efek Indonesia (BEI) memberikan sanksi kepada Garuda Indonesia dan konsultan akuntan publiknya (Lastanti, 2020). Selain itu, beberapa waktu lalu, PT Perusahaan Gas Negara (Persero) Tbk. terseret media dalam kasus sengketa pajak dengan Direktorat Jenderal Pajak (DJP) yang terdiri dari 4 pokok sengketa. Sengketa tersebut membuat publik berasumsi bahwa PGAS telah melakukan fraud pada laporan keuangannya. Oleh karena itu, agar dapat meminimalisirkan kemungkinan terjadinya fraud dalam perusahaan, maka penelitian ini dilakukan. Penelitian ini dilakukan dengan tujuan untuk mengetahui apakah perusahaan telah melakukan fraud dengan menggunakan teknik financial shenanigans.

\section{TINJAUAN PUSTAKA}

\section{Kasus PT Perusahaan Gas Negara (Persero) Tbk.}

PT Perusahaan Gas Negara (Persero) Tbk. sendiri sudah sejak lama mengalami persoalan pajak dengan Direktorat Jenderal Pajak (Hafiyyan, 2021). Yang terbaru pada bulan Januari tahun 2021, PGAS mengalami sengketa pajak lagi dengan Direktorat Jenderal Pajak (DJP). Berdasarkan berita yang dilancir CNBC Indonesia (Wareza, 2021), sengketa ini terjadi karena DJP menganggap penyerahan gas bumi yang dilakukan PGAS untuk periode tahun 
2014-2017 merupakan objek pajak, sedangkan perusahaan menanggap transaksi yang terjadi bukan merupakan objek pajak. Kasus pajak ini sendiri bernilai Rp 6,88 triliun. Kasus ini sendiri melatarbelakangi Perusahaan Gas Negara (Persero) Tbk. digunakan sebagai objek dari penelitian ini.

\section{Financial Statement Fraud}

Financial statement fraud adalah sebuah kecurangan yang dilakukan dengan menyajikan laporan keuangan yang tidak menyajikan keadaan perusahaan yang sesungguhnya sehingga dapat memberikan gambaran yang salah kepada pembaca laporan terhadap kinerja perusahaan. Kecurangan pada laporan keuangan dapat dilakukan dengan menaikkan nilai aset, pendapatan dan keuntungan secara berlebihan serta menurunkan nilai liabilitas, biaya dan kerugian secara berlebihan. Kecurangan pada laporan keuangan pada umumnya dilakukan dengan tujuan untuk menarik perhatian para investor untuk menginvestasi pada perusahaan, mengeliminasikan persepsi buruk perusahaan pada pasar, memperoleh harga jual akuisisi yang lebih tinggi, mencapai tujuan dari perusahaan dan untuk memperoleh insentif yang berhubungan dengan kinerja perusahaan (Noble, 2019). Beberapa penelitian terdahulu menganalisis ada atau tidaknya tindakan fraud menggunakan teori fraud triangle (Utama, Ramantha, \& Badera, 2018), fraud diamond (Yesiariani \& Rahayu, 2016; Suryani, 2019) maupun fraud pentagon (Bayagub, Wafirotin, \& Mustoffa, 2018; Vivianita \& Indudewi, 2019). Pada penelitian ini, analisis yang digunakan adalah dengan menggunakan tujuh teknik financial shenanigans yang dikembangkan oleh Howard Mark Schilit dalam bukunya berjudul "How to Detect Accounting Gimmicks \& Fraud in Financial Reports".

\section{Financial shenanigans}

Financial shenanigans adalah segala bentuk tindakan yang bertujuan untuk memberikan gambaran mengenai laporan keuangan yang salah. Financial shenanigans berkaitan erat dengan kecurangan laporan keuangan. Financial shenanigans dapat diartikan juga sebagai perilaku atau tindakan-tindakan curang yang digunakan oleh suatu perusahaan dalam melakukan kecurangan laporan keuangan (Jamieson et al., 2019).

Financial shenanigans yang digunakan oleh perusahaan dalam melakukan fraud dibagi menjadi tujuh kelompok besar yaitu: pencatatan pendapatan yang terlalu cepat atau dengan nominal yang diragukan; pencatatan pendapatan yang fiktif; peningkatan laba dengan menggunakan keuntungan yang diperoleh dari transaksi one-time; pemindahan biaya periode sekarang pada periode sebelum atau sesudahnya; tidak atau kurangnya pencatatan liabilitas perusahaan; pemindahan pendapatan periode sekarang pada periode yang akan datang; pemindahan biaya periode yang akan datang pada periode sekarang dengan menggunakan special charge. Tujuh kelompok besar financial shenanigans tersebut terbagi menjadi beberapa teknik khusus yang menjelaskan bagaimana perusahaan dapat melakukan kecurangan dalam penyajian laporan keuangan.

Financial shenanigans no. 1 yaitu mengenai pencatatan dan pengakuan perusahaan. (Perler \& Engelhart, 1993). Shenanigans ini dapat dilakukan dengan 6 teknik yang dapat dibagikan menjadi 2 kelompok. Kelompok pertama adalah mencatat pendapatan terlalu cepat, yaitu seperti mencatat pendapatan dari masa yang akan datang ketika produk/jasa belum disediakan, mencatat pendapatan sebelum pengiriman atau diterima pelanggan, dan pencatatan pendapatan yang dimana pelanggan tidak berkewajiban untuk membayar. Kelompok kedua adalah pencatatan pendapatan yang mencurigakan seperti penjualan kepada pihak berrelasi, memberikan sesuatu kepada pelanggan yang bernilai sama (quid pro quo), dan menaikkan pendapatan secara sengaja (Schilit, 2010).

Financial shenanigans no.2 yaitu mengenai pencatatan pendapatan yang fiktif. Shenanigans ini dapat dilakukan dengan 5 teknik yaitu mencatatkan pendapatan yang tidak memiliki substansi ekonomi, pencatatan kas yang diperoleh dari pinjaman bank sebagai pendapatan, pencatatan atas keuntungan yang berasal dari investasi atau penjualan aset tetap, pencatatan diskon atau retur pembelian sebagai pendapatan perusahaan, dan menahan pendapatan perusahaan target untuk meningkatkan pendapatan perusahaan setelah merger (Schilit, 2010). 
Financial shenanigans no.3 yaitu mengenai peningkatan laba dengan menggunakan transaksi one-time. Shenanigans ini dapat dilakukan dengan 4 teknik yaitu meningkatkan keuntungan perusahaan dengan menjual aset yang dihargai dengan harga di atas nilai bukunya untuk memperoleh keuntungan yang besar ketika menjualnya, mengakui laba dari keuntungan investasi sebagai pendapatan operasional, mencatat keuntungan investasi sebagai pengurangan biaya operasional, mereklasifikasi akun laporan posisi keuangan (Schilit, 2010).

Financial shenanigans no.4 yaitu mengenai pemindahan biaya periode sekarang pada periode sebelum atau sesudahnya. Shenanigans ini dapat dilakukan dengan 5 teknik yaitu mengkapitalisasi biaya operasi, mengalihkan beban saat ini ke periode sebelumnya dengan mengubah kebijakan akuntansi, meningkatkan umur aset untuk mengurangi beban depresiasi atau amortisasi pada tahun berjalan, tidak mencatat pencadangan penurunan nilai aset, dan mengurangi pencadangan penurunan nilai aset (Schilit, 2010).

Financial shenanigans no.5 yaitu mengenai tidak atau kurangnya pencatatan liabilitas perusahaan. Shenanigans ini dapat dilakukan dengan 5 teknik yaitu tidak mencatat biaya atau liabilitas ketika terdapat obligasi yang masih harus dipenuhi sehingga dapat meningkatkan laba periode tahun yang berjalan, teknik yang berhubungan dengan fleksibilitas yang dimiliki manajemen dalam hal memilih kebijakan dan estimasi akuntansi yaitu untuk pencatatan imbalan pensiun atau sewa, melepaskan cadangan biaya khusus untuk meningkatkan pendapatan di periode berikutnya, membuat potongan harga fiktif, mencatat pendapatan pada saat kas diterima meskipun masih terdapat kewajiban di masa depan. Penerimaan pendapatan yang masih memiliki obligasi yang harus dipenuhi dicatat oleh perusahaan sebagai pendapatan di terima dimuka yang merupakan kewajiban perusahaan (Schilit, 2010).

Financial shenanigans no.6 yaitu mengenai pemindahan pendapatan periode sekarang pada periode yang akan datang yang umumnya digunakan untuk memanajemen laba. Shenanigans ini dapat dilakukan dengan 2 teknik yaitu membentuk cadangan pada periode perusahaan yang memiliki operasional yang baik untuk membantu dalam menetapkan nominal laba dan kemudian melepaskan cadangan tersebut pada periode perusahaan memiliki operasional yang kurang baik dengan tujuan untuk memberikan gambaran bahwa perusahaan memperoleh laba. Perusahaan dapat mengunakan teknik yaitu pendapatan yang diperoleh oleh perusahaan target akan ditahan sebelum proses akuisisi siap dilakukan, sehingga hal ini menyebabkan pendapatan yang dilaporkan perusahaan setelah akuisisi akan meningkat sebab perusahaan yang mengakuisisi akan mencatat pendapatan yang ditahan tersebut pada periode tahun akuisisi perusahaan target tersebut (Schilit, 2010).

Financial shenanigans no.7 yaitu mengenai pemindahan biaya periode yang akan datang pada periode sekarang dengan menggunakan special charge. Shenanigans ini umumnya dilakukan oleh perusahaan yang mengalami masalah going-concern. Shenanigans ini dapat dilakukan dengan 3 teknik yaitu meningkatkan one-time charge, meningkatkan beban untuk penelitian dan pengembangan, dan mengakui beban yang akan memberikan manfaat ekonomis bagi perusahaan. Pengakuan biaya yang dipercepat ini bertujuan untuk mempercantik laporan pada periode selanjutnya, sehingga perusahaan seakan-akan memiliki laba yang tinggi walaupun sebenarnya perusahaan mengalami kerugian apabila mengikutsertakan biaya-biaya yang timbul di periode tersebut (Schilit, 2010).

\section{METODE PENELITIAN}

Pendekatan yang digunakan dalam penelitian ini adalah pendekatan kualitatif. Menurut Sugiyono (2007), data kualitatif merupakan data yang tidak berupa angka atau bilangan melainkan berbentuk kata, kalimat, atau gambar.

Penelitian ini dilakukan dengan membandingkan laporan keuangan yang dipublikasikan oleh PT. Perusahaan Gas Negara (Persero) Tbk. atau disingkat PGAS dengan periode penelitian tahun 2016 hingga 2020. Perbandingan dilakukan untuk menunjang analisis agar dapat menarik sebuah kesimpulan. 
Data yang digunakan dalam penelitian ini merupakan data sekunder yaitu data yang tidak didapatkan langsung dari sumbernya. Data sekunder tersebut diperoleh melalui laporan keuangan yang dipublikasikan oleh PT. Perusahaan Gas Negara (Persero) Tbk. pada situs resmi perusahaan. Teknik pengumpulan data dilakukan dengan library research method yaitu melalui berbagai sumber kepustakaan seperti jurnal, buku, dan laporan keuangan perusahaan.

Penelitian ini memanfaatkan metode penulisan yang bersifat deskriptif kualitatif sehingga dalam melakukan sebuah analisis kualitatif, peneliti menggunakan teknik berupa analisis konten (content analysis). Analisis konten dapat diartikan sebagai penelitian yang bersifat deskripsi dengan cara menjelaskan sebuah isi informasi secara mendalam yang dimana informasi tersebut dapat diperoleh dari berbagai sumber konten media yang nantinya bertujuan sebagai referensi ataupun pendukung dalam pelaksanaan penelitian ini (Prita, Wardayat, Liyati, \& MS, 2020).

\section{HASIL DAN PEMBAHASAN}

\section{Financial shenanigans no.1}

Berdasarkan laporan keuangan PGAS untuk tahun 2016-2020, perusahaan mengakui pendapatan dan penjualan berdasarkan tiga kondisi. Ketiga kondisi yang perlu dipenuhi tersebut antara lain jumlah pendapatan dapat dihitung dengan andal, terdapat keuntungan ekonomi yang memungkinkan untuk diteruskan pada perusahaan, dan biaya yang akan dan telah dikeluarkan bersamaan dengan proses penjualan harus dihitung secara akurat. Namun sejak 1 Januari 2020, perusahaan menerapkan PSAK No. 72 dalam pengakuan pendapatannya. Berdasarkan PSAK itu pula, perusahaan mengakui pendapatannya ketika barang atau jasa yang dijanjikan ke pelanggan telah dipenuhi yaitu menggunakan metode fob shipping point.

Perusahaan ini memiliki transaksi penjualan yang dilakukan kepada entitas berelasi yaitu PLN dengan nilai mencapai 27,13\% dari jumlah pendapatan neto pada tahun 2020. Angka ini dinilai meningkat dari $21,19 \%$ pada tahun 2016. Pada tahun 2020 sendiri nilai piutang usaha perusahaan sebesar $46,45 \%$ merupakan piutang terhadap pihak berelasi. Nilai ini terbilang cukup besar namun wajar karena sebagian besar pihak berelasi tersebut adalah PLN dan Pertamina yang memang dalam proses produksi masing-masing perusahaan tersebut membutuhkan pasokan gas yang besar.

PT Perusahaan Gas Negara (Persero) Tbk. belum pernah tercatat melakukan transaksi berupa pemberian sesuatu yang bernilai sama sebagai pengganti kepada pelanggannya. Selama periode tahun 2016-2020, pendapatan perusahaan cenderung tidak begitu stabil. Pada tahun 2017 dimana terjadi kenaikan sebesar 21,66\%. Namun kenaikan ini disebabkan oleh akuisisi yang dilakukan PT Perusahaan Gas Negara (Persero) Tbk. terhadap Pertagas (Pertamina) dan SESL. Di tahun 2020 sendiri terjadi penurunan sekitar 25,03\% dan angka ini dinilai wajar karena adanya pandemi COVID-19 pada tahun tersebut yang menyebabkan ekonomi menurun. Penutupan perusahaan-perusahaan yang ada berdampak secara langsung maupun tidak langsung terhadap PGAS. Banyaknya perusahaan yang tutup atau bangkrut, atau pemberlakuan work from home menyebabkan pemakaian listrik industri menurun sehingga berdampak juga pada pemasokan gas kepada tenaga-tenaga pembangkit listrik di Indonesia.

Hasil analisis financial shenanigans no.1 pada PT Perusahaan Gas Negara (Persero) Tbk. menyatakan bahwa tidak terdapat praktik kecurangan yang berhubungan dengan financial shenanigan no. 1. Hal ini menyatakan bahwa PT Perusahaan Gas Negara (Persero) Tbk dalam melakukan pencatatan dan pengakuan terhadap pendapatan perusahaan telah dilakukan sesuai dengan standar dan wajar. 
Financial shenanigans no.2

Tabel 1.

Teknik 1 (Financial Shenanigans No.2)

\begin{tabular}{|c|c|c|c|c|c|}
\hline & 2016 & 2017 & 2018 & 2019 & 2020 \\
\hline $\begin{array}{l}\text { Pendapat } \\
\text { an (USD) }\end{array}$ & $\begin{array}{c}2.934 .778 .71 \\
0\end{array}$ & $\begin{array}{c}3.570 .597 .76 \\
1\end{array}$ & $\begin{array}{c}3.870 .266 .73 \\
8\end{array}$ & $\begin{array}{c}3.848 .717 .68 \\
4\end{array}$ & $\begin{array}{c}2885.536 .10 \\
5\end{array}$ \\
\hline $\begin{array}{c}\text { Perubaha } \\
n\end{array}$ & & & & & \\
\hline $\begin{array}{c}\text { pendapata } \\
\text { n (\%) }\end{array}$ & $-4,37 \%$ & $21.66 \%$ & $8.39 \%$ & $-0.56 \%$ & $-25.03 \%$ \\
\hline $\begin{array}{l}\text { Piutang } \\
\text { (USD) }\end{array}$ & 321.164 .700 & 503.040 .415 & 540.925 .366 & 509.519 .451 & 472.596 .381 \\
\hline Perubaha & & & & & \\
\hline $\begin{array}{l}\text { n piutang } \\
(\%)\end{array}$ & $12,06 \%$ & $56.63 \%$ & $7.53 \%$ & $-5.81 \%$ & $-7.25 \%$ \\
\hline $\begin{array}{l}\text { Piutang / } \\
\text { endapatan } \\
\text { Days of }\end{array}$ & 0,109434043 & 0,14088409 & 0,139764363 & 0,132386808 & 0,163781136 \\
\hline $\begin{array}{c}\text { receivable } \\
s\end{array}$ & 39,94342575 & 51,42269272 & 51,01399256 & 48,3211851 & 59,78011461 \\
\hline
\end{tabular}

Sumber : (Perusahaan Gas Negara)

Teknik pertama yaitu mencatatkan pendapatan dari transaksi yang tidak memiliki substansi ekonomi. Pada laporan tahunan dan catatan keuangan laporan perusahaan disebutkan bahwa pada umumnya PGAS akan membentuk kontrak perjanjian dengan pelanggan dan pemasok. Berdasarkan dengan pengungkapan yang dilakukan perusahaan maka dapat dinyatakan tidak terdapat kontrak sampingan selain kontrak perjanjian yang telah disetujui dan sah. Peningkatan pendapatan yang juga disebabkan terdapatnya regulasi baru yang mengatur industri, peningkatan permintaan volume gas dan distribusi yang dilakukan perusahaan atau kegiatan akuisisi Pertagas yang dilakukan oleh perusahaan pada akhir tahun 2018. Proporsi antara piutang usaha dengan pendapatan umumnya berbanding lurus, namun untuk tahun 2020 menyebabkan proporsi piutang dan pendapatan untuk meningkat drastis yang dapat disebabkan oleh Covid-19 yang menyebabkan dampak pada perekonomian Indonesia dan beberapa industri. Namun dalam hal ini masih dapat dikatakan wajar sebab kenaikan proporsi dari piutang untuk setiap peningkatan dan penurunannya masih hanya mengalami perbedaan $1-3 \%$ per tahunnya. Kenaikan $4 \%$ pada perbandingan piutang/pendapatan tahun 2017 terjadi akibat dari penyajian kembali laporan keuangan perusahaan sebagai akibat dari akuisisi Pertagas.

Tabel 2.

Teknik 2 (Financial Shenanigans No.2)

\begin{tabular}{|c|c|c|c|c|c|}
\hline & 2016 & 2017 & 2018 & 2019 & 2020 \\
\hline $\begin{array}{c}\text { Pinjaman } \\
\text { jangka panjang }\end{array}$ & 1.296 .315 .710 & 413.732.667 & 496.515 .768 & 357.077 .074 & 354.419 .502 \\
\hline Perubahan (\%) & $3,42 \%$ & $-68,08 \%$ & $20,01 \%$ & $-28,08 \%$ & $-0,74 \%$ \\
\hline $\begin{array}{l}\text { Pelunasan } \\
\text { pinjaman }\end{array}$ & (121.177.638) & $(1.029 .733 .463)$ & (28.610.302) & $(134.212 .041)$ & \\
\hline $\begin{array}{c}\text { Penerimaan } \\
\text { pinjaman }\end{array}$ & & & 100.000 .000 & & \\
\hline
\end{tabular}

Sumber : (Perusahaan Gas Negara)

Teknik kedua yaitu pencatatan kas dari kegiatan pendanaan yaitu pinjaman bank dalam pendapatan. Perusahaan dalam hal ini mengakui pinjaman bank yang dilakukan sebagai liabilitas perusahaan dan diklasifikasikan pinjaman bank tersebut sesuai jangka 
waktunya, serta transaksi perusahaan yang berkaitan dengan pinjaman bank tersebut telah benar dicatat baik ketika penerimaan pinjaman atau pada saat pelunasan pinjaman. Hal ini menyatakan bahwa pengklasifikasian liabilitas dan pendapatan telah benar dilakukan.

Teknik ketiga yaitu pencatatan keuntungan dari penjualan aset atau investasi dalam pendapatan. PGAS mengakui penjualan aset tetap tersebut pada laporan laba rugi perusahaan dan perusahaan tidak melakukan penjualan aset untuk tahun 2016-2020 sehingga tidak memunculkan keuntungan atau kerugian dari transaksi tersebut. Keuntungan yang diperoleh dari kegiatan aset kerja sama operasi diakui sebagai pendapatan diterima dimukayang kemudian akan diakui sesuai dengan periode kerjasama operasi. Entitas ventura bersama perusahaan dicatat dengan menggunakan metode ekuitas sehingga keuntungan dan kerugian dari ventura tersebut dicatat pada laporan laba rugi perusahaan sesuai dengan persentase kepemilikan perusahaan pada entitas tersebut pada akun yang terpisah yaitu bagian laba atau rugi dari ventura bersama. Sehingga dalam hal ini menyatakan bahwa pencatatan keuntungan dari investasi yang dilakukan perusahaan telah benar dilakukan dan tidak menyebabkan salah pencatatan pada pendapatan.

Tabel 3.

Teknik 4 (Financial Shenanigans No.2)

\begin{tabular}{cccccc}
\hline & 2016 & 2017 & 2018 & 2019 & 2020 \\
\hline Pendapatan (USD) & 2.934 .778$. & 3.570 .597$. & 3.870 .266$. & 3.848 .717$. & 2.885 .536$. \\
Beban pokok & 710 & 761 & 738 & 684 & 105 \\
pendapatan (USD) & 2.047 .838$. & 2.389 .088$. & 2.560 .766$. & 2.621 .348$. & 2.031 .118$. \\
Analisis vertikal (Rasio) & 771 & 310 & 539 & 716 & 705 \\
Persediaan (USD) & 65.293 .22 & $66,91 \%$ & $66,17 \%$ & $68,11 \%$ & $70,39 \%$ \\
& 7 & 74.182 .10 & 78.508 .47 & 70.797 .77 & 68.893 .97 \\
& 1 & 8 & 9 & 5 \\
\hline
\end{tabular}

Sumber : (Perusahaan Gas Negara)

Teknik keempat yaitu pencatatan diskon atau retur pembelian menjadi pendapatan perusahaan. Dalam hal ini, perusahaan tidak memiliki diskon atau retur pembelian yang dapat digunakan oleh perusahaan dalam melakukan fraud tersebut. Peningkatan permintaan produk perusahaan menyebabkan perusahaan untuk harus menyuplai produk tersebut sehingga pembelian yang dilakukan perusahaan akan semakin meningkat. Jika dilihat dari perbandingan rasio beban pokok pendapatan dan pendapatan, maka dapat dinyatakan bahwa masih wajar, yang disebabkan rasio untuk kelima tahunnya berada di kisaran $66-70 \%$ serta untuk setiap tahunnya tidak terdapat perubahan yang signifikan pada rasio tersebut. Selain itu dapat dilihat bahwa kenaikan atau penurunan rasio tersebut juga memiliki hubungan yang berbanding terbalik dengan persediaan akhir perusahaan. Hal ini dapat dikatakan wajar sebab jika pembelian yang dilakukan sesuai dengan kontrak dengan volume yang tetap maka jika beban pokok penjualan turun akan menyebabkan persediaan akhir untuk meningkat dan begitu juga sebaliknya.

Teknik kelima yaitu menahan pendapatan dari perusahaan target untuk meningkatkan pendapatan perusahaan setelah merger telah selesai dilakukan. Dalam hal ini, perusahaan tidak melakukan merger dengan perusahaan apapun sehingga menyebabkan perusahaan untuk tidak dapat melakukan fraud melalui teknik ini.

Hasil analisis financial shenanigans no.2 pada PT Perusahaan Gas Negara (Persero) Tbk. menyatakan bahwa tidak terdapat praktik kecurangan yang berhubungan dengan financial shenanigan no. 2. Hal ini menyatakan bahwa PT Perusahaan Gas Negara (Persero) Tbk tidak melakukan pencatatan pendapatan yang fiktif sehingga laporan keuangan telah disajikan sesuai dengan standar dan wajar. 
Financial shenanigans no.3

Tabel 4.

Teknik 1 (Financial Shenanigans No.3)

\begin{tabular}{|c|c|c|c|c|c|}
\hline & 2016 & 2017 & 2018 & 2019 & 2020 \\
\hline $\begin{array}{l}\text { Persediaan } \\
\text { (USD) }\end{array}$ & 65.293 .227 & 74.182 .101 & 78.508 .478 & 70.797.779 & 68.893 .975 \\
\hline $\begin{array}{l}\text { Kenaikan / } \\
\text { (Penuruna } \\
\text { n) } \\
\text { Harga }\end{array}$ & $50,26 \%$ & $13,61 \%$ & $5,83 \%$ & $-9,82 \%$ & $-2,68 \%$ \\
\hline Pokok & 2.047.838.77 & 2.389.088.31 & 2.560 .766 .53 & 2.621.348.71 & 2.031 .118 .70 \\
\hline $\begin{array}{l}\text { Pendapata } \\
\text { n (USD) }\end{array}$ & 1 & 0 & 9 & 6 & 5 \\
\hline $\begin{array}{l}\text { Kenaikan / } \\
\text { (Penuruna } \\
\text { n) }\end{array}$ & $-2,47 \%$ & $16,66 \%$ & $7,18 \%$ & $2,37 \%$ & $-22,5 \%$ \\
\hline
\end{tabular}

Sumber : (Perusahaan Gas Negara)

Teknik pertama yaitu meningkatkan keuntungan perusahaan dengan menjual aset yang dihargai dengan harga di atas nilai bukunya untuk memperoleh keuntungan yang besar ketika menjualnya. Dalam laporan keuangan tahun 2016-2020 yang dipublikasikan oleh PT. Perusahaan Gas Negara (Persero) Tbk., terlihat bahwa untuk nilai persediaan yang dicatat dalam neraca meskipun nilai nya fluktuatif namun dari segi persentase tingkat peningkatan maupun penurunan nya tidak mengalami perubahan yang signifikan pula. Dari catatan atas laporan keuangan yang dipublikasikan, disana tertulis bahwa biaya perolehan ditentukan dengan metode rata-rata bergerak serta pencatatan persediaan telah sesuai dengan standar akuntansi umum yang berlaku. Selain itu, dalam catatan laporan keuangan dinyatakan juga bahwa PGAS menerapkan metode akuisisi untuk mencatat kombinasi bisnis. Imbalan yang dialihkan untuk akuisisi suatu entitas anak adalah sebesar nilai wajar aset yang dialihkan, liabilitas yang diakui terhadap pemilik pihak yang diakusisi sebelumnya dan kepentingan ekuitas yang diterbitkan oleh perusahaan.

Tabel 5.

Teknik 2 (Financial Shenanigans No.3)

\begin{tabular}{lccccc}
\hline & 2016 & 2017 & 2018 & 2019 & 2020 \\
\hline $\begin{array}{l}\text { Pendapata } \\
\text { n (USD) }\end{array}$ & 2.934 .778 .71 & 3.570 .597 .76 & 3.870 .266 .73 & 3.848 .717 .68 & 2.885 .536 .10 \\
$\begin{array}{l}\text { Kenaikan } / \\
\text { (Penuruna }\end{array}$ & 0 & 1 & 8 & 4 & 5 \\
n) & $-4,36 \%$ & $21,66 \%$ & $8,39 \%$ & $-5,56 \%$ & $-25,02 \%$ \\
\hline
\end{tabular}

Sumber: (Perusahaan Gas Negara)

Teknik kedua yaitu mengakui laba dari keuntungan investasi sebagai pendapatan operasional. Ditinjau dari catatan atas laporan keuangan, perincian dalam atas pendapatan perusahaan terdiri dari kegiatan distribusi gas bumi, jasa transmisi minyak dan gas bumi, penjualan minyak mentah, gas bumi, LPG, LNG, dan jasa lainnya yang dimana telah sesuai dengan segmen usaha yang dimiliki dan tidak ada pendapatan non operasional yang digabungkan kedalam pendapatan tersebut. 
Tabel 6.

Teknik 3 (Financial Shenanigans No.3)

\begin{tabular}{lccccc}
\hline & $\mathbf{2 0 1 6}$ & $\mathbf{2 0 1 7}$ & $\mathbf{2 0 1 8}$ & $\mathbf{2 0 1 9}$ & $\mathbf{2 0 2 0}$ \\
\hline $\begin{array}{l}\text { Pendapata } \\
\mathrm{n}(\text { USD) }\end{array}$ & 2.934 .778 .71 & 3.570 .597 .76 & 3.870 .266 .73 & 3.848 .717 .68 & 2.885 .536 .10 \\
$\begin{array}{l}\text { Kenaikan / } \\
\text { (Penuruna }\end{array}$ & 0 & 1 & 8 & 4 & 5 \\
n) & $-4,36 \%$ & $21,66 \%$ & $8,39 \%$ & $-5,56 \%$ & $-25,02 \%$ \\
$\begin{array}{l}\text { Beban } \\
\text { Operasiona }\end{array}$ & 442.697 .716 & 666.609 .311 & 664.191 .251 & 681.035 .220 & 550.702 .489 \\
I & & & & & \\
(USD) & & & & & \\
$\begin{array}{l}\text { Kenaikan / } \\
\text { (Penuruna } \\
\text { n) }\end{array}$ & $9,07 \%$ & $50,57 \%$ & $-0,36 \%$ & $2,53 \%$ & $-19,1 \%$ \\
\hline
\end{tabular}

Sumber: (Perusahaan Gas Negara)

Teknik ketiga yaitu mencatat keuntungan investasi sebagai pengurangan biaya operasional. Berdasarkan tabel perhitungan diatas, terlihat terdapat perubahan persentase yang cukup signifikan dari tahun 2016 menuju ke tahun 2017 yaitu sebesar 50,57\%. Hal ini disebabkan dikarenakan adanya akuisisi pada perusahaan Pertagas, namun bila merujuk catatan atas laporan keuangan, secara terperinci dalam akun biaya operasional telah diakui biaya-biaya yang sesuai dengan standar akuntasi yang dimana merupakan biaya yang dikeluarkan secara operasional untuk mendapatkan pendapatan utama perusahaan.

Dalam catatan atas laporan keuangan perusahaan gas negara, dinyatakan bahwa aset eksplorasi dan evaluasi yang ditangguhkan terdiri dari biaya-biaya yang terjadi setelah izin ekplorasi diperoleh dan sebelum dimulainya pengembangan lapangan minyak dan gas bumi antara lain mencakup akumulasi biaya yang terkait dengan penyelidikan umum, administrasi dan perizinan, geologi, dan geofisika. Aset eksplorasi dan evaluasi dinilai untuk penurunannya pada saat bukti dan keadaan yang menunjukkan bahwa nilai tercatat aset tersebut mungkin melebihi jumlah yang dapat dipulihkan. Aset eksplorasi dan evaluasi direklasifikasi ke properti minyak dan gas pada saat kelayakan teknis dan komersialitas dari minyak dan gas yang diekstraksi tersebut dapat dibuktikan.

Hasil analisis financial shenanigans no.3 pada PT Perusahaan Gas Negara (Persero) Tbk. menyatakan bahwa tidak terdapat praktik kecurangan yang berhubungan dengan financial shenanigan no. 3. Hal ini menyatakan bahwa PT Perusahaan Gas Negara (Persero) Tbk tidak melakukan peningkatan laba dengan menggunakan transaksi one-time sehingga laporan keuangan telah disajikan sesuai dengan standar dan wajar.

\section{Financial shenanigans no.4}

Teknik pertama adalah mengkapitalisasi biaya operasi yang memberikan manfaat jangka pendek dan mengalihkan biaya tersebut ke periode mendatang. Biaya yang paling sering dikapitalisasi yaitu biaya pemasaran, biaya bunga, biaya pengembangan perangkat lunak, dan biaya perbaikan dan pemeliharaan. Biaya-biaya tersebut biasanya langsung dibebankan pada periode berjalan. Akan tetapi, sering ditemukan perusahaan yang mengkapitalisasi biaya tersebut sebagai aset sehingga angka yang disajikan pada laporan keuangan menjadi tidak wajar. 
Tabel 7.

Teknik 1 (Financial Shenanigans No.4)

\begin{tabular}{|c|c|c|c|c|c|}
\hline & 2016 (USD) & 2017 (USD) & 2018 (USD) & 2019 (USD) & 2020 (USD) \\
\hline $\begin{array}{c}\text { Beban } \\
\text { perbaikan } \\
\text { dan } \\
\text { pemeliharaa }\end{array}$ & 24.763.243 & 14.820 .912 & 16.438 .949 & 10.231 .157 & 8.903 .478 \\
\hline $\begin{array}{c}n \\
\text { Aset tetap }\end{array}$ & $\begin{array}{c}2.861 .408 .87 \\
6\end{array}$ & $\begin{array}{c}2.897 .063 .23 \\
0\end{array}$ & $\begin{array}{c}2.861 .408 .87 \\
6\end{array}$ & $\begin{array}{c}2.747 .699 .60 \\
2\end{array}$ & $\begin{array}{c}2.697 .687 .57 \\
7\end{array}$ \\
\hline
\end{tabular}

Sumber : (Perusahaan Gas Negara)

Pada laporan keuangan PT Perusahaan Gas Negara (Persero) Tbk atau PGAS periode 2016 hingga 2020, tidak ditemukan pengkapitalisasian biaya perbaikan dan pemeliharaan. Hal ini dapat dilihat dari penurunan biaya setiap tahunnya, terkecuali di tahun 2017. Akan tetapi, kenaikan biaya di tahun 2017 tidak menimbulkan kecurigaan karena apabila biaya tersebut dikapitalisasi, aset tetap pada tahun 2017 akan meningkat. Dari data di atas, dapat dilihat bahwa terjadi penurunan pada jumlah aset tetap di tahun 2017.

Kecurangan yang dilakukan pada teknik pertama memungkinkan perusahaan untuk mengalihkan biaya ke periode mendatang. Teknik kedua digunakan manajemen perusahaan untuk menghilangkan biaya tersebut dari laporan keuangan. Dengan mengubah kebijakan akuntansi, biaya yang timbul di periode berjalan dibebankan pada periode sebelumnya, sehingga laba perusahaan pada periode berjalan meningkat. Penyajian laporan keuangan PGAS telah disusun sesuai Standar Akuntansi Keuangan di Indonesia. Perubahan pada PSAK telah diungkapkan pada catatan atas laporan keuangan dan telah dibuat penyesuaian berdasarkan ketentuan PSAK.

Pada teknik ketiga, perusahaan dapat meningkatkan pendapatan dengan memperpanjang umur suatu aset, sehingga biaya depresiasi atau amortisasi yang diakui semakin sedikit. Semakin lama umur suatu aset, semakin lama pula aset tersebut akan disajkan pada laporan posisi keuangan yang menyebabkan aset perusahaan menggelembung. Selain itu, biaya depresiasi atau amortisasi yang rendah dapat menaikkan laba perusahaan.

Dari tahun 2016 hingga 2018, PGAS menggunakan metode garis lurus untuk penyusutan bangunan dan prasarana dan metode saldo menurun ganda untuk seluruh aset tetap lainnya. Pada tahun 2019, tepatnya sejak 1 Januari 2019, PGAS mengubah seluruh metode penyusutan menjadi garis lurus. Hal ini dikarenakan adanya perkembangan bisnis dan reviu manajemen atas pola konsumsi manfaat ekonomi aset tetap di industri infrastruktur gas bumi. Perubahan ini berlaku secara prospektif, yang berarti hanya akan berakibat pada laba rugi periode berjalan dan periode mendatang. Berikut merupakan estimasi umur manfaat aset tetap:

Tabel 8.

Estimasi Umur Manfaat Aset Tetap

\begin{tabular}{lccc}
\hline \multirow{2}{*}{ Aset tetap } & \multirow{2}{*}{ Tahun } & \multicolumn{2}{c}{ Tarif } \\
\cline { 3 - 4 } & 20 & $2016-2018$ & $2019-2020$ \\
\hline Bangunan dan prasarana & $20.5 \%-5 \%$ \\
Mesin dan peralatan & $16-20$ & $10 \%-12.5 \%$ & $5 \%-6.25 \%$ \\
Kendaraan bermotor & $4-8$ & $25 \%-50 \%$ & $12.5 \%-25 \%$ \\
Peralatan kantor & $4-8$ & $25 \%-50 \%$ & $12.5 \%-25 \%$ \\
Peralatan dan perabot & $4-8$ & $25 \%-50 \%$ & $12.5 \%-25 \%$ \\
Aset belum terpasang & 16 & $12.5 \%$ & $6.25 \%$ \\
\hline
\end{tabular}

Sumber : (Perusahaan Gas Negara)

Perubahan pada metode penyusutan berdampak pada penurunan biaya depresiasi dari USD227.067.395 pada tahun 2018 menjadi USD191.910.720 pada tahun 2019 atau 
penurunan sebesar USD14.138.537. Penurunan tersebut tidak mengindikasikan adanya praktik kecurangan karena laba operasi perusahaan pada tahun 2019 mengalami penurunan sebesar $18.64 \%$.

Teknik keempat yaitu tidak mengakui biaya penurunan nilai pada aset. Suatu aset dikatakan overvalued ketika nilai buku lebih besar dari nilai wajarnya. Aset tertentu seperti persediaan dan piutang usaha sering mengalami overvalued ketika perusahaan tidak mencadangkan nilai penurunannya. Hal tersebut menyebabkan laba perusahaan meningkat.

Penerapan teknik kelima tidak berbeda jauh dengan teknik keempat, yaitu digunakan untuk mengurangi nilai pencadangan aset. Pencadangan nilai penurunan biasanya ditemukan pada akun persediaan, piutang usaha, aset tetap, dan goodwill. Pengurangan pencadangan dilakukan agar biaya semakin kecil dan laba perusahaan semakin besar.

Pada setiap akhir periode pelaporan, PGAS akan menilai apakah terjadi penurunan nilai pada aset keuangannya, salah satunya adalah piutang usaha. Apabila terdapat bukti objektif bahwa PGAS tidak dapat menagih utang tersebut, maka jumlah nilai terutang akan disisihkan atau dihapus langsung dan dibebankan pada laba rugi. Sama halnya dengan piutang, penyisihan atas persediaan yang telah usang akan dilakukan berdasarkan bukti objektif atas dasar hasil pemeriksaan secara berkala terhadap kondisi persediaan. Berikut merupakan rincian biaya cadangan kerugian penurunan nilai:

Tabel 9.

Teknik 5 (Financial Shenanigans No.4)

\begin{tabular}{lccccc}
\hline & 2016 (USD) & 2017 (USD) & 2018 (USD) & 2019 (USD) & 2020 (USD) \\
\hline $\begin{array}{l}\text { Cadangan } \\
\text { kerugian } \\
\text { penurunan nilai }\end{array}$ & 15.174 .554 & 4.136 .726 & 15.804 .030 & 50.847 .676 & 3.276 .557 \\
\hline
\end{tabular}

Sumber : (Perusahaan Gas Negara)

Pada tahun 2020, biaya cadangan kerugian penurunan nilai menurun sebesar 93.55\%. Penurunan drastis tersebut dikarenakan adanya pemulihan nilai cadangan.

Hasil analisis financial shenanigans no.4 pada PT Perusahaan Gas Negara (Persero) Tbk. menyatakan bahwa tidak terdapat praktik kecurangan yang berhubungan dengan financial shenanigan no. 4. Hal ini menyatakan bahwa PT Perusahaan Gas Negara (Persero) Tbk tidak melakukan pemindahan biaya periode sekarang pada periode sebelum atau sesudahnya sehingga laporan keuangan telah disajikan sesuai dengan standar dan wajar.

\section{Financial shenanigans no.5}

Dalam catatan atas laporan keuangan perusahaan gas negara, telah mengakui biaya dan kewajiban terkait sesuai dengan standar akuntansi yang berlaku yang dimana PT. PGAS menggunakan standar PSAK 57 sebagai pedoman dalam mengklarifikasi akuntansi liabilitas untuk membayar pungutan.

PT Perusahaan Gas Negara (Persero) Tbk. dalam catatan atas laporan keuangan disebutkan bahwa perusahaan dalam melakukan estimasi dan pertimbangan selalu dievaluasi berdasarkan pengalaman historis dan faktor-faktor lain, termasuk ekspektasi peristiwa masa depan yang diyakini wajar berdasarkan kondisi yang ada. Kemudian, perusahaan gas negara juga selalu membuat estimasi dan asumsi mengenai masa depan. Estimasi akuntansi yang dihasilkan, menurut definisi, akan jarang sekali sama dengan hasil aktualnya. Oleh karena itu, estimasi dan asumsi yang secara signifikan berisiko menyebabkan penyesuaian material akan selalu dilaporkan melalui catatan atas laporan keuangan ini.

Dalam catatan laporan keuangan PGAS, menyebutkan bahwa setiap estimasi cadangan dan faktor penilaian cadangan telah dilaporkan secara keseluruhan dalam catatan atas laporan keuangan. Contohnya, nilai tercatat untuk deplesi, penyusutan dan untuk amortisasi beserta pemulihan nilai tercatat properti minyak dan gas, yang digunakan untuk memproduksi minyak dan gas tergantung pada estimasi cadangan minyak dan gas. Faktor utama yang mempengaruhi estimasi tersebut adalah penilaian teknis atas kuantitas produksi cadangan minyak dan gas yang ada dan kendala ekonomis seperti ketersediaan pasar 
komersial atas produksi minyak dan gas bumi maupun asumsi yang terkait dengan antisipasi harga komoditas dan biaya pengembangan dan produksi cadangan tersebut. Selain itu, PGAS juga menerapkan cadangan kerugian ekspektasian seumur hidup untuk seluruh piutang usaha. Untuk mengukur kerugian kredit ekspektasian, piutang usaha telah dikelompokkan berdasarkan karakteristik risiko kredit dan waktu jatuh tempo yang serupa.

Tabel 10.

Teknik 5 (Financial Shenanigans No.5)

\begin{tabular}{|c|c|c|c|c|c|}
\hline & 2016 & 2017 & 2018 & 2019 & 2020 \\
\hline Beban & & & & & \\
\hline $\begin{array}{c}\text { Pokok } \\
\text { Pendapata } \\
n \\
\text { (USD) }\end{array}$ & $\begin{array}{c}2.047 .838 .77 \\
1\end{array}$ & $\begin{array}{c}2.389 .088 .31 \\
0\end{array}$ & $\begin{array}{c}2.560 .766 .53 \\
9\end{array}$ & $\begin{array}{c}2.621 .348 .71 \\
6\end{array}$ & $\begin{array}{c}2.031 .118 .70 \\
5\end{array}$ \\
\hline $\begin{array}{c}\text { Kenaikan / } \\
\text { (Penuruna } \\
n)\end{array}$ & $-2,74 \%$ & $16,6 \%$ & $7,18 \%$ & $2,36 \%$ & $-22,51 \%$ \\
\hline
\end{tabular}

Sumber : (Perusahaan Gas Negara)

Teknik keempat yaitu membuat potongan harga fiktif. Dalam tabel diatas, terlihat bahwa bahwa terdapat peningkatan beban pokok pendapatan pada tahun 2017 yang dimana disebabkan hasil konsolidasi dengan Pertagas. Sedangkan, di tahun 2020 mengalami penurunan beban pokok pendapatan sebesar $-22,51 \%$ dari tahun 2019 . Hal ini disebabkan karena adanya pandemi COVID-19 sehingga menyebabkan penjualan yang turun serta beban pokok pendapatan juga ikut menurun. Secara keseluruhan, perubahan persentase tersebut meskipun fluktuatif tapi masih dapat dikatakan wajar karena ada sebab dibalik peningkatan maupun penurunan itu. Merujuk dalam catatan atas laporan keuangan, tidak adanya disebutkan adanya potongan pembelian. Oleh karena itu, hanya bisa menilai dari beban pokok pendapatan.

Tabel 11.

Teknik 6 (Financial Shenanigans No.5)

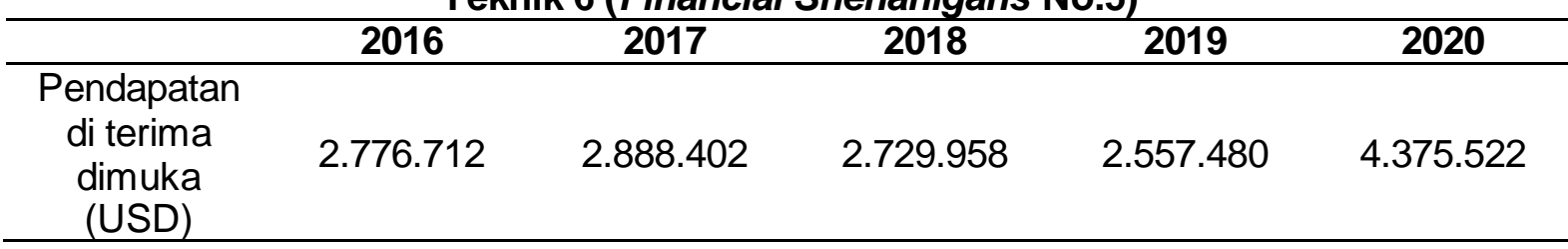

Sumber : (Perusahaan Gas Negara)

Teknik kelima yaitu mencatat pendapatan pada saat kas diterima meskipun masih terdapat kewajiban di masa depan. Dari tabel diatas, terlihat bahwa PGAS juga telah mengakui pendapatan diterima dimuka sesuai standar akuntansi yang berlaku. Dalam catatan atas laporan keuangan, diungkapkan bahwa PGAS memiliki aset kerjasama operasi yang dimana merupakan tanah Perusahaan yang digunakan untuk menyelenggarakan kegiatan kerjasama operasi. Bangunan kantor yang diperoleh sebagai kompensasi dalam kerjasama operasi dan pendapatan diterima di muka terkait diakui pada saat aset tersebut selesai dikerjakan dan siap digunakan sesuai dengan tujuannya. Pendapatan diterima di muka diakui selama periode kerjasama operasi.

Berdasarkan analisis financial shenanigan no. 5 ini juga tidak ditemukan adanya tindakan yang dilakukan perusahaan untuk berusaha menyembunyikan pengeluaran pajak atas transaksi gas bumi. Berdasarkan laporan keuangan PT Perusahaan Gas Negara (Persero) Tbk., perusahaan telah membayar kewajiban pajak mereka yang semestinya. Namun kasus tersebut terjadi tidak lain karena DJP yang menyatakan penyerahan gas bumi yang dilakukan PT Perusahaan Gas Negara (Persero) Tbk. merupakan objek pajak ketika perusahaan optimis transaksi tersebut sudah diakui sebagai objek tidak kena pajak oleh Kemenkeu. 
Hasil analisis financial shenanigans no.5 pada PT Perusahaan Gas Negara (Persero) Tbk. menyatakan bahwa tidak terdapat praktik kecurangan yang berhubungan dengan financial shenanigan no. 5. Hal ini menyatakan bahwa PT Perusahaan Gas Negara (Persero) dalam melakukan pencatatan liabilitas perusahaan telah sesuai dengan standar dan wajar.

Financial shenanigans no.6

Tabel 12.

Teknik 1 (Financial Shenanigans No.6)

\begin{tabular}{cccccc}
\hline & 2016 & 2017 & 2018 & 2019 & 2020 \\
\hline $\begin{array}{c}\text { Pendapatan } \\
\text { (USD) }\end{array}$ & 2.934 .778 .710 & 3.570 .597 .761 & 3.870 .266 .738 & 3.848 .717 .684 & 2.885 .536 .105 \\
$\begin{array}{c}\text { Laba (rugi) } \\
\text { bersih (USD) } \\
\text { GPM }\end{array}$ & 308.583 .916 & 253.288 .744 & 364.638 .660 & 112.981 .195 & $(215.767 .814)$ \\
$\begin{array}{c}\text { Pendapatan } \\
\text { dimuka } \\
\text { (USD) }\end{array}$ & $10,51 \%$ & $7,09 \%$ & $9,42 \%$ & $2,94 \%$ & $-7,48 \%$ \\
\hline
\end{tabular}

Sumber : (Perusahaan Gas Negara)

Teknik pertama yaitu membentuk cadangan dari laba yang diperoleh dari pendapatan untuk dapat digunakan oleh perusahaan untuk meningkatkan performa perusahaan disaat keadaan yang tidak baik. Cadangan yang dibentuk oleh PGAS pada umumnya adalah untuk mencatat estimasi cadangan atas deplesi, penyusutan dan amortisasi serta pemulihan atau penurunan nilai aset minyak dan gas dalam memproduksi produk tersebut. Perusahaan akan melakukan impairment test setiap tahun, dan hal ini menyebabkan peningkatan atau penurunan pada provisi penurunan nilai tersebut. Pada tahun 2018, perusahaan melakukan restrukturisasi dengan tujuan untuk meningkatkan kegiatan operasional perusahaan agar lebih efektif dan efisien sehingga dibentuk unit bisnis produk perusahaan serta dilakukan untuk menyesuaikan regulasi baru yang telah dibentuk. Hal ini menyebabkan perusahaan untuk lebih efisien sebab terdapat peningkatan pada pendapatan yang disebabkan oleh meningkatnya permintaan produk. Pendapatan dimuka yang diterima oleh perusahaan juga relatif stabil sehingga dapat menyatakan bahwa perusahaan tidak menggunakan pendapatan dimuka yang merupakan liabilitas dalam membantu meningkatkan laba, sebab setiap tahun terdapat nominal pendapatan dimuka yang relatif stabil sehingga dapat dinyatakan bahwa perusahaan tidak melakukan teknik ini.

Teknik kedua adalah pendapatan yang diperoleh oleh perusahaan target akan ditahan sebelum proses akuisisi siap dilakukan dan pencatatan pendapatan tersebut dilakukan sesudah merger selesai dilakukan. Perusahaan melakukan akuisisi Pertagas pada tahun 2018 dan memiliki kepemilikan saham 51\%, sehingga menyebabkan perusahaan untuk melakukan konsolidasi. Hal ini menyebabkan perusahaan untuk menyajikan kembali laporan keuangan tahun 2017. Perusahaan yang menjadi target yaitu Pertagas tidak memiliki perubahan yang signifikan pada pendapatan yang disajikan pada tahun akuisisi dengan tahun sebelumnya sehingga dapat menyatakan bahwa perusahaan yang mengakuisisi tidak menginstruksikan perusahaan target untuk menahan pendapatan atau laba. Akusisi yang dilakukan PGAS adalah untuk mencapai efisiensi dalam hal biaya serta membantu perusahaan untuk menjadi perusahaan penyedia energi yang terintegrasi melalui produk dan servis yang berhubungan dengan gas. Akuisisi tersebut dilakukan setelah melihat prospek dari Pertagas yang baik dan dilakukan dengan tujuan untuk membantu PGAS dalam mencapai integrasi nasional dalam mengekspansi infrastruktur gas dan bisnisnya.

Hasil analisis financial shenanigans no.6 pada PT Perusahaan Gas Negara (Persero) Tbk. menyatakan bahwa tidak terdapat praktik kecurangan yang berhubungan dengan financial shenanigan no. 6. Hal ini menyatakan bahwa PT Perusahaan Gas Negara (Persero) Tbk tidak melakukan pemindahan pendapatan periode sekarang pada periode yang akan 
datang yang umumnya digunakan untuk memanajemen laba sehingga laporan keuangan telah disajikan sesuai dengan standar dan wajar.

\section{Financial shenanigans no.7}

Teknik pertama yaitu menggelembungkan one-time charge. One-time charge disebut juga sebagai nonrecurring charge atau biaya yang hanya muncul sekali yang kemungkinan besar biaya tersebut tidak akan muncul lagi di kemudian hari, contohnya biaya konsolidasi, biaya kombinasi bisnis, biaya reorganisasi dan restrukturisasi, biaya perancangan bisnis, dan lainnya.

Dari data laporan keuangan PGAS periode 2016 hingga 2020, tidak ditemukan adanya transaksi one-time charge. Biasanya teknik ini digunakan oleh manajer baru dalam suatu perusahaan. Manajer menggunakan kesempatan ini untuk menggelembungkan biaya dan mengakui biaya masa depan pada periode berjalan sehingga biaya pada periode selanjutnya berkurang. Walaupun jumlah biaya yang dicatat lumayan besar, akan tetapi investor jarang mempertanyakan hal ini, karena dianggap sebagai special charge.

Teknik kedua dilakukan dengan cara menghapus biaya $R \& D$ (research and development) dari proses akuisisi. Perusahaan melakukan akuisisi dan menghapus sebagian besar biaya akuisisinya yang dianggap sebagai "acquired in-process $R \& D$ ". Penghapusan biaya tersebut berpengaruh terhadap berkurangnya biaya operasional di periode berjalan dan periode yang akan datang yang akan menyebabkan peningkatan pada laba perusahaan.

Kombinasi bisnis PGAS menggunakan metode akuisisi. Biaya yang timbul dalam proses akuisisi dibebankan pada saat terjadinya. Apabila kombinasi bisnis dilakukan melalui tahapan tertentu, maka nilai wajar pada tanggal akuisisi akan dinilai kembali. Pada periode 2016 hingga 2019, PGAS melakukan akuisisi terhadap SESL (dahulu British Petroleum East Kalimantan Pte. Ltd), SIPBV (dahulu Kufpec Indonesia Pangkah B.V), SIPL (dahulu Hess (Indonesia Pangkah) Limited, SPLLC (dahulu Hess Pangkah LLC), SEML (dahulu SROL) dan Pertagas. Dari pengakuisisian tersebut, tidak ditemukan adanya kecurangan dalam penghapusan biaya dari proses akuisisi.

Teknik ketiga yaitu mempercepat pengakuan biaya diskresioner. Apabila target perusahaan pada periode berjalan sudah tercapai, terkadang perusahaan mencoba untuk mengalihkan biaya periode selanjutnya pada periode yang sedang berjalan. Hal yang harus diperhatikan adalah meningkatnya biaya dibayar dimuka, berkurangnya periode depresiasi atau amortisasi akibat perubahan kebijakan akuntansi.

Tabel 13.

Teknik 3 (Financial Shenanigans No.7)

\begin{tabular}{|c|c|c|c|c|c|}
\hline & 2016 (USD) & 2017 (USD) & 2018 (USD) & 2019 (USD) & $\begin{array}{c}2020 \\
\text { (USD) }\end{array}$ \\
\hline $\begin{array}{c}\text { Beban } \\
\text { dibayar di } \\
\text { muka }\end{array}$ & 24.432.083 & 30.319 .103 & 27.867.213 & 16.642 .510 & 7.379 .651 \\
\hline
\end{tabular}

Sumber : (Perusahaan Gas Negara)

Komponen beban dibayar di muka terdiri dari joint interest billing dari aktivitas minyak dan gas, arrangement fee, dan sewa. Kenaikan biaya pada 2017 disebabkan karena adanya penambahan sebesar USD15.788.135 pada beban sewa dibayar di muka. Pengakuan biaya diskresioner yang disebabkan oleh perubahan kebijakan akuntansi telah dijelaskan pada Shenanigan 4 dan tidak ditemukan adanya kecurangan.

Hasil analisis financial shenanigans no.7 pada PT Perusahaan Gas Negara (Persero) Tbk. menyatakan bahwa tidak terdapat praktik kecurangan yang berhubungan dengan financial shenanigan no. 7. Hal ini menyatakan bahwa PT Perusahaan Gas Negara (Persero) Tbk tidak melakukan pemindahan biaya periode yang akan datang pada periode sekarang dengan menggunakan special charge sehingga laporan keuangan telah disajikan sesuai dengan standar dan wajar. 


\section{PENUTUP}

Dari analisis yang dilakukan terhadap laporan keuangan PT Perusahaan Gas Negara (Persero) Tbk. periode 2016 hingga 2020 menggunakan tujuh teknik financial shenanigans, tidak ditemukan adanya tindakan fraud. Dalam pelaporan keuangannya, PGAS tidak menerapkan ketujuh teknik tersebut. Hal ini menyatakan bahwa laporan keuangan disajikan oleh PT Perusahaan Gas Negara (Persero) Tbk. telah wajar berdasarkan tingkat materialitasnya.

Sengketa pajak yang terjadi antara PT Perusahaan Gas Negara (Persero) Tbk. dengan DJP sendiri bukan merupakan pelanggaran menggunakan financial shenanigans. Persoalan ini terjadi bukan karena PT PGAS berusaha menyembunyikan kewajiban pajak mereka. Perusahaan dianggap tidak berusaha untuk menghindari pembayaran pajak, namun kasus ini terjadi karena pengakuan objek pajak yang ambigu diantara kedua belah pihak.

Penelitian yang dilakukan memiliki beberapa keterbatasan yaitu penelitian dilakukan dengan menggunakan data sekunder yaitu laporan keuangan yang telah diaudit dari situs resmi perusahaan dan bukan dengan data primer. Tanda-tanda financial shenanigans pada laporan keuangan perusahaan hendaknya diperhatikan dengan khusus agar dapat mengurangi terjadinya kecurangan laporan keuangan yang dapat menyebabkan kerugian besar pada ekonomi negara. Diharapkan bahwa untuk penelitian selanjutnya, pendeteksian financial shenanigans untuk setiap teknik dapat dilakukan dengan menganalisis akun lain yang diperkirakan memiliki hubungan dengan teknik yang dibahas.

\section{DAFT AR PUSTAKA}

Bayagub, A., Wafirotin, K. Z., \& Mustoffa, A. F. (2018). Analisis Elemen-Elemen Fraud Pentagon Sebagai Determinan Fraudulent Financial Reporting (Studi Pada Perusahaan Property dan Real Estate Yang Terdaftar Di Bursa Efek Indonesia Periode 2014-2016). ISOQUANT: Jurnal Ekonomi, Manajemen Dan Akuntansi, 2(2), 1. https://doi.org/10.24269/iso.v2i2.184

Hafiyyan. (2021, January). Begini Kronologis Sengketa Pajak PGN (PGAS) dan DJP sejak 2012 - Market Bisnis.com.

Jamieson, D., Awolowo, I. F., Garrow, N., Winfield, J., \& Bhaiyat, F. (2019). Financial shenanigans: The importance of anti-fraud education. Journal of Governance and Regulation, 8(3), 58-63. https://doi.org/10.22495/jgr_v8_i3_p5

Kuruppu, N. (2020). Uncovering Financial Shenanigans: Benford's Law as a Computer Assisted Analytical Procedure. International Journal of Business and Management, 15(7), 37. https://doi.org/10.5539/ijbm.v15n7p37

Lastanti, H. S. (2020). Role of Audit Committee in the Fraud Pentagon and Financial Statement Fraud. International Journal of Contemporary Accounting, 2(1), 77. https://doi.org/10.25105/ijca.v2i1.7163

Negara, P. G. (n.d.). Financial Information.

Noble, M. R. (2019). Fraud diamond analysis in detecting financial statement fraud. The Indonesian Accounting Review, 9(2), 121. https://doi.org/10.14414/tiar.v9i2.1632

Perler, J., \& Engelhart, Y. (1993). Financial shenanigans: how to detect accounting gimmicks and fraud in financial reports. Choice Reviews Online, Vol. 31, pp. 31-0401-31-0401. https://doi.org/10.5860/choice.31-0401

Prita, S., Wardayat, S. M., Liyati, E., \& MS, A. F. (2020). Profiling Selebriti Fraud: Analisis Profil Koruptor di Indonesia. Jurnal Akuntansi Dan Pajak, 20(2), 266-275. https://doi.org/10.29040/jap.v20i2.874

Sakti, E., Tarjo, T., Prasetyono, P., \& Riskiyadi, M. (2020). Detection of Fraud Indications in Financial Statements Using Financial Shenanigans. Asia Pacific Fraud Journal, 5(2), 277. https://doi.org/10.21532/apfjournal.v5i2.170

Schilit, H. M. (2010). Accounting Financial-Shenanigans (pp. 1-20). pp. 1-20.

Sugiyono. (2007). Statistik Untuk Penelitian.pdf. 
Suryani, I. C. (2019). Analisis Fraud Diamond Dalam Mendeteksi Financial Statement Fraud: Studi Empiris Pada Perusahaan Manufaktur Yang Terdaftar Di Bursa Efek Indonesia (Bei) Tahun 2016 - 2018. Prosiding Seminar Nasional Cendekiawan, 2. https://doi.org/10.25105/semnas.v0i0.5780

Utama, I. G. P. O. S., Ramantha, I. W., \& Badera, I. D. (2018). Analisis Faktor-Faktor Dalam Perspektif Fraud Triangle Sebagai Prediktor Fraudulent Financial Reporting. E-Jurnal Akuntansi Universitas Udayana, 7(1), 251-278.

Vivianita, A., \& Indudewi, D. (2019). Financial Statement Fraud Pada Perusahaan Pertambangan Yang Dipengaruhi Oleh Fraud Pentagon Theory (Studi Kasus Di Perusahaan Tambang Yang Terdaftar Di Bei Tahun 2014-2016). Jurnal Dinamika Sosial Budaya, 20(1), 1. https://doi.org/10.26623/jdsb.v20i1.1229

Wareza, M. (2021, January). Terungkap! Begini Awal Mula Sengketa Pajak PGN Rp 6,88 T.

Yesiariani, M., \& Rahayu, I. (2016). Analisis Fraud Diamond dalam Mendeteksi Financial Statement Fraud (Studi Empiris pada Perusahaan LQ-45 yang Terdaftar di Bursa Efek Indonesia Tahun 2010 - 2014). Simposium Nasional Akuntansi XIX, Lampung, 1-22.

Yesiariani, M., \& Rahayu, I. (2017). Deteksi financial statement fraud: Pengujian dengan fraud diamond. Jurnal Akuntansi \& Auditing Indonesia, 21(1), 49-60. https://doi.org/10.20885/jaai.vol21.iss1.art5 